\title{
Analysis of the accuracy of the gradient method for determining the mean integral refractive index of air
}

\author{
P.I. Neyezhmakov, A.V. Prokopov \\ National Scientific Centre "Institute of Metrology", Myronosytska Str., 42, 61002, Kharkiv, Ukraine \\ alexander.prokopov@metrology.kharkov.ua
}

\begin{abstract}
The article is devoted to the problem of improving the accuracy of taking into account the influence of the Earth's atmosphere on the results of distance measurements carried out using electromagnetic waves. The main influencing factors in such measurements are the difference between the speed of propagation of an electromagnetic signal in the atmosphere and the speed of light in a vacuum, as well as the refractive distortion of the trajectory along which the signal propagates.

To eliminate the influence of the atmosphere, special corrections are used, which are applied into the measurement results in order to compensate for the above influencing factors. The most important among them is the correction, which takes into account the mean integral refractive index of air along the trace being measured.

At present, as a rule, model methods for determining the correction are used, taking into account the mean integral refractive index of air. These methods use a point approximation of continuous functions describing the spatial distribution of temperature, pressure and air humidity on the trace being measured, as well as the representation of the finite sum of a certain integral specifying the exact correlation for the correction. Due to these limitations in the framework of the commonly used model methods, it is not always possible to achieve the required accuracy of the results of distance measurements. As for the well-known hardware methods, which are potentially more accurate, they are still under development. In this regard, new possibilities of improving the accuracy of model methods, in particular, the recently proposed gradient method, are considered.

Theoretical studies of the accuracy of the gradient method for determining the mean integral refractive index of air in distance measurements on near-Earth traces are carried out. It is shown that it is more accurate than the well-known trapezium method. The equations of measurement of the gradient method obtained with the use of Hermite interpolation polynomials, which are valid for non-uniform partition of the measured trace by points in which the local values of the refractive index are determined, are considered. The requirements for the procedure and accuracy of measurements of the parameters necessary for determining the gradients of the refractive index of air at the end points of the trace in the framework of the gradient method are substantiated.

The results of the studies provide a rigorous justification for new methods for determining the mean integral refractive index of air on near-Earth traces with a non-uniform profile of the underlying surface in the presence of significant elevation differences.
\end{abstract}

Keywords: distance measurements, mean integral refractive index of air, interpolation, Hermite polynomial.

Received: 12.12 .2018

Edited: 26.12 .2018

Approved for publication: 28.12.2018

\section{Problem statement}

The most significant factors currently limiting the accuracy of distance measurement on near-Earth traces are, as is known [1-3], the difference between the propagation speed of an electromagnetic signal of a range finder in the atmosphere and the speed of light in a vacuum, as well as the curvature of the trajectory along which the signal propagates due to refraction effect.

The influence of these factors can be compensated either by introducing the corresponding independently determined corrections into the measurement results, or by instrumental means directly during the measurements. The most urgent problem, the solution of which is of great practical importance, is precisely the problem of accounting for the influence of the atmosphere on the speed of signal propagation. Such accounting can be carried out using the mean integral refractive index of air along the trace being measured

$$
\bar{n}=D^{-1} \int_{0}^{\sigma_{\mathrm{D}}} n(r(\sigma)) d \sigma .
$$


The integration in the formula (1) is performed along the ray path $\sigma$ (from the starting point of the path $\sigma=0$ to the end point $\sigma=\sigma_{\mathrm{D}}$ ); the path configuration is determined by the ray equation of geometric optics [4]; $n(r)$ is the dependence of the refractive index of air $n$ on the coordinates $r=r(x, y, z) ; D$ is the length of the path corresponding to the length of the line being measured.

The determination of the value $\bar{n}$ is possible both on the basis of model representations of the profile $n(r)$ and integral (1) and by instrumental means directly during the measurements. Among the model representations, the so-called point approximation methods are often used, which are based on the representation of the integrand function or the integral (1) itself as a sum of terms defined at certain fixed points of the trace being measured. For the instrumental approach, the most well-known are geodesic and dispersion methods [1-3].

Given the complexity of the practical implementation, as well as the limitations laid down in the basis of instrumental methods (in particular, the neglect of the refractive spatial spread of the paths of signals with different optical carrier wavelengths - for dispersive methods [2], as well as the use of the concept of the mean integral refractive index for geodetic methods [3]), in this paper, the accuracy possibilities of model methods using approximation principles are considered, namely, the methods based on the representation of integral (1) as a finite sum ([5-7]).

Further, the main results achieved to date in the study of these methods are analyzed, the prospects for their further development are discussed.

\section{Presentation of the main material}

The working relation for the point approximation method, based on the calculation of the integral (1) using the trapezium formula, is as follows [8]

$$
\bar{n}_{\mathrm{T}}=\left[\frac{n_{0}+n_{\mathrm{D}}}{2}+\sum_{i=1}^{N-1} n\left(\sigma_{\mathrm{i}}\right)\right] \cdot \frac{1}{N}+R_{\mathrm{T}},
$$

where $\sigma_{\mathrm{i}}=D \cdot \frac{i}{N} ; i=1,2, \ldots N-1 ; N$ is the number of partitions of the integration interval by the points at which the local values of refractive index are measured ( $N+1$ is the number of these points); $R_{\mathrm{T}}$ is the remainder of the representation of integral (1) by the finite sum (2).

Using the Euler-Maclaurin integration formula [8], relying on the integral representations of the ray equations of geometric optics proposed in $[9,10]$, relation (1), in the case of the gradient method for determining the mean integral refractive index of air, can be represented as [5-7]:

$$
\begin{aligned}
& \bar{n}_{\mathrm{EM}}=\left[\frac{n_{0}+n_{\mathrm{D}}}{2}+\sum_{i=1}^{N-1} n\left(\sigma_{\mathrm{i}}\right)\right]-\frac{D}{12 N^{2}}\left(g_{\mathrm{G}_{\mathrm{D}}} \cdot \sin Z_{\mathrm{D}}-\right. \\
& \left.-g_{\mathrm{V}_{\mathrm{D}}} \cdot \cos Z_{\mathrm{D}}-g_{\mathrm{G}_{0}} \cdot \sin Z_{0}-g_{\mathrm{V}_{0}} \cdot \cos Z_{0}\right)+R_{\mathrm{EM}},
\end{aligned}
$$

where $z_{\mathrm{L}}$ and $z_{0}$ are the visible zenith angles (taking into account refraction) at the end points of the trace; $g_{G_{L}}, g_{V_{L}}, g_{G_{0}}$ and $g_{V_{0}}$ are the values of horizontal and vertical projections of the refractive index of air at these points; $R_{\mathrm{EM}}$ is the remainder of the representation of integral (1) by the finite sum (3).

The disadvantage of methods (2), (3) is the requirement of uniform partition of the integration interval by points, in which local values of the refractive index are determined. This requirement can not always be fulfilled in practice, so it was proposed [11] to improve the gradient method by using for calculating integral (1) the Hermite interpolation polynomial [12] instead of the Euler-Maclaurin integration formula. In the case when the representation of the profile of the refractive index by a Hermite polynomial is carried out only by the values of the refractive index at $N+1$ point of the trace and the values of the first derivatives of the refractive index by the ray coordinate at the endpoints of the trace, the following relation for $\bar{n}$ can be obtained [13] from the formula (1):

$$
\begin{aligned}
& \bar{n}_{\mathrm{E}} \cdot D=\sum_{i=1}^{N-1} A_{\mathrm{i}} \cdot n\left(\sigma_{\mathrm{i}}\right)+ \\
& +\sum_{i=0, N}\left[A_{\mathrm{i} 0} \cdot n\left(\sigma_{\mathrm{i}}\right)+A_{\mathrm{i} 1} \cdot n^{(1)}\left(\sigma_{\mathrm{i}}\right)\right]+\int_{0}^{D} R_{\mathrm{E}} \cdot d \sigma,
\end{aligned}
$$

where

$$
A_{\mathrm{i}}=\left[\frac{\sigma-\sigma_{\mathrm{i}}}{\Omega(\sigma)}\right]_{\sigma=\sigma_{\mathrm{i}}} \cdot \int_{0}^{D} \frac{\Omega(\sigma)}{\sigma-\sigma_{\mathrm{i}}} \cdot d \sigma \text { at } i=1, \ldots, N-1,
$$

$A_{\mathrm{i} 0}=\left[\frac{\left(\sigma-\sigma_{\mathrm{i}}\right)^{2}}{\Omega(\sigma)}\right]_{\sigma=\sigma_{\mathrm{i}}} \cdot \int_{0}^{D} \frac{\Omega(\sigma) \cdot d \sigma}{\left(\sigma-\sigma_{\mathrm{i}}\right)^{2}}+\left[\frac{\left(\sigma-\sigma_{\mathrm{i}}\right)^{2}}{\Omega(\sigma)}\right]_{\sigma=\sigma_{\mathrm{i}}}^{(1)} \cdot \int_{0}^{D} \frac{\Omega(\sigma) \cdot d \sigma}{\sigma-\sigma_{\mathrm{i}}}$ at $i=0, N$,

$$
A_{\mathrm{i} 1}=\left[\frac{\left(\sigma-\sigma_{\mathrm{i}}\right)^{2}}{\Omega(\sigma)}\right]_{\sigma=\sigma_{\mathrm{i}}} \cdot \int_{0}^{\mathrm{D}} \frac{\Omega(\sigma) \cdot d \sigma}{\sigma-\sigma_{\mathrm{i}}} \text { at } i=0, N,
$$

where $n\left(\sigma_{\mathrm{i}}\right), n^{(1)}\left(\sigma_{\mathrm{i}}\right)$ - respectively, the values of the refractive index and the first derivative of the refractive index at the point $\sigma=\sigma_{\mathrm{i}} ; \Omega(\sigma)=\sigma^{2}\left(\sigma-\sigma_{1}\right) \cdot(\sigma-$ $\left.-\sigma_{2}\right) \cdot \ldots \cdot\left(\sigma-\sigma_{\mathrm{N}-1}\right)(\sigma-D)^{2} ; R_{\mathrm{E}}$ - remainder of the Hermite polynomial representation of the dependence of the refractive index of air on the ray coordinate.

It is easy to show $[5,11]$ that the values $n^{(1)}\left(\sigma_{\mathrm{i}}\right)$ in the formula (4) can be expressed in terms of horizontal and vertical projections of the refractive index gradient and visible zenith angles at the end points of the trace similar to (3), therefore (4) is a generalization of the gradient method (3). 
Using relations (2), (3), (4), a comparative assessment of the potential accuracy of methods for determining $\bar{n}$ can be performed by comparing the maximum values of the remainders in these ratios, since these remainders are neglected in practical application of methods based on (2), (3), (4). This is an overassessment, but it allows to determine which method has the best accuracy capabilities.

According to $[8,12-14]$, the formulas for calculating the remainders are

$$
R_{\mathrm{T}}=\left.\frac{D^{2}}{12 \cdot N^{2}} \cdot \frac{d^{2} n}{d \sigma^{2}}\right|_{\sigma=\sigma_{* *}}
$$

using the trapezium method (2);

$$
R_{\mathrm{EM}}=\left.\frac{D^{4}}{720 N^{4}} \cdot \frac{d^{4} n}{d \sigma^{4}}\right|_{\sigma=\sigma_{*}}
$$

using Euler-Maclaurin expansion (3);

$$
R_{\mathrm{E}}=\frac{n^{(N+3)}\left(\sigma_{* * *}\right)}{(N+3) !} \cdot \Omega(\sigma)
$$

using Hermite interpolation (4). In formulas (5) - (7) for the remainders, the values of the ray coordinate $\sigma_{*}, \sigma_{* *}, \sigma_{* * *}$ correspond to the maximum of the magnitude of these members in the integration interval.

When estimating the maximum remainders, it is necessary to take into account that the order of magnitude of each of them according to formulas (5) - (7) is determined by the order of the derivative of the refractive index of the ray coordinate included in these formulas. Since the result of each differentiation is reduced to the appearance in these formulas the factors $\sim g \cdot D$ (where $g=\frac{d n}{d \sigma}, D-$ length of the trace being measured), then, given that $g \cdot D<<1$, it is easy to conclude that the gradient method, based on the use of EulerMaclaurin or Hermite expansions, always gives more accurate results than the trapezium method. The most accurate is the variant using Hermite expansions (since the order of the derivative in the remainder of the Hermite interpolation, in the presence of intermediate points, always exceeds the order of the derivative for the remainder of the Euler-Maclaurin expansion).

The Euler-Maclaurin expansion (3) and Hermite interpolation (4) give identical results only in case $N=1$, when the local values of the refractive index and its gradient (derivative of the ray coordinate) are determined only at the end points of the trace (when intermediate points are not included). In the presence of intermediate points, the results do not coincide even with a uniform distribution of these points along the trace. For example, in the case of one additional point in the middle of the trace, when $N=2$, formula (4) is reduced to the relation [11]

$$
\bar{n}=\frac{1}{30} \cdot\left[7\left(n_{0}+n_{\mathrm{D}}\right)+16 n\left(\sigma=\frac{D}{2}\right)\right]+\frac{D}{60} \cdot\left[n_{0}^{(1)}-n_{\mathrm{D}}^{(1)}\right]
$$

that no longer coincides with (3) at $N=2$.

Requirements for the accuracy of determining the individual quantities in formulas (2) - (4) are established in the traditional way - on the basis of differentiating these formulas for each of the quantities being determined, followed by an evaluation of the obtained partial derivatives (influence coefficients). For local values of the refractive index (determined by pressure, temperature and humidity of air at a controlled point), as well as visible zenith angles, such assessments have been repeatedly performed (see [1-3], etc.). Additional consideration is required only when assessing the accuracy requirements for determining the gradients of the refractive index of air included in formulas (3), (4).

For formula (3), for example, these requirements are established on the basis of an assessment of the error (uncertainty) component of the determination of $\bar{n}$, due to inaccurate knowledge of the magnitude of the gradient $g$, which can be represented by the relation [5]

$$
m_{\bar{n}_{\mathrm{g}}}=\frac{\sqrt{2} \cdot m_{\mathrm{g}} \cdot D}{12 \cdot N^{2}}
$$

where $m_{\mathrm{g}}-$ gradient determination error. Hence, the requirement for the upper limit of the magnitude $m_{\mathrm{g}}$ can be established, if a condition is imposed on the magnitude $m_{\bar{n}_{g}}$, for example, $m_{\bar{n}_{g}} \leqslant 5 \cdot 10^{-8}$.

The ratio for $g$ in the case of determining the gradient of the three-point scheme within the finite difference method with an intermediate point corresponding to the point $\sigma_{0}$, at which the derivative is determined, can be represented as $[12,15]$

$$
\left.g\right|_{\sigma=\sigma_{0}}=\frac{n\left(\sigma_{ \pm}\right)-n\left(\sigma_{\mp}\right)}{\Delta \sigma},
$$

where $\Delta \sigma=\sigma_{ \pm}-\sigma_{\mp}$;

$$
\sigma_{0}=\frac{\sigma_{ \pm}-\sigma_{\mp}}{2}
$$

$\sigma_{ \pm}, \sigma_{0}, \sigma_{\mp}-$ coordinates of points on the ray for a three-point gradient determination scheme.

The random component of the error in determining the quantity $g$ according to (9) can be represented as

$$
\tilde{m}_{\mathrm{g}}=m_{\mathrm{n}} \cdot \frac{\sqrt{2}}{\Delta \sigma},
$$

where $m_{\mathrm{n}}-$ the error in determining the local values of the refractive index (the errors in determining the distances between points, at which the local values of the refractive index are determined, are assumed to be insignificant).

The assessment of the maximum systematic error is determined by the magnitude of the remainder neglected in (9), which has the form [12, 15] 


$$
\Delta_{\text {gmax }}=\left.\frac{d^{3} n}{d \sigma^{3}}\right|_{\max } \cdot \frac{(\Delta \sigma)^{2}}{24} .
$$

The total error with the confidence probability $p$ can be represented by the ratio

$$
m_{\mathrm{g}}=\left.\frac{d^{3} n}{d \sigma^{3}}\right|_{\max } \cdot \frac{(\Delta \sigma)^{2}}{24}+k_{\mathrm{s}} \cdot m_{\mathrm{n}} \cdot \frac{\sqrt{2}}{\Delta \sigma},
$$

where $k_{\mathrm{s}}-$ Student's coefficient for confidence probability $p$.

It can be seen that the dependence $m_{\mathrm{g}}$ on $\Delta \sigma$ (i. e., on the distance between the points at which the values of the refractive index are measured for determining the gradient) according to (10) is non-monotonic. The minimum value $m_{\mathrm{g}}$ will correspond to the optimal distance between the specified points.

$$
\Delta \sigma_{\mathrm{opt}}=\left(\frac{k_{\mathrm{s}} \cdot m_{\mathrm{n}} \cdot 12 \sqrt{2}}{\left|\frac{d^{3} n}{d \sigma^{3}}\right|_{\max }}\right)^{\frac{1}{3}} .
$$

For average measurement conditions, the quantity (11) is of the order of $10^{2} \mathrm{~m}$. More accurate quantitative requirements both for the scheme of placing the measurement points of local values of the refractive index for determining the gradient and for determining the accuracy of these local values can be established on the basis of a natural or numerical experiment.

\section{Conclusions}

The analysis of model methods for taking into account the mean integral refractive index of air for distance measurements on near-Earth traces was carried out. The accuracy possibilities of the gradient method were considered for both uniform and non-uniform partition of the measured trace by points in which local values of the refractive index were determined. The requirements for the accuracy of determining the gradients of the refractive index of air at the end points of the trace were formulated. The results of the performed research can be used for the development and practical testing of methods for determining the mean integral refractive index of air on near-Earth traces with a non-uniform profile of the underlying surface in the presence of significant elevation differences. In this connection, further research of the accuracy of the gradient method with the use of model or experimental data on refractive index profiles on near-Earth traces are of interest.

\title{
Аналіз точності градієнтного методу визначення середньоінтегрального показника заломлення повітря
}

\author{
П.І. Неєжмаков, О.В. Прокопов \\ Національний науковий центр “ннтитут метрології", вул. Мироносицька, 42, 61002, Харків, Україна \\ alexander.prokopov@metrology.kharkov.ua
}

\section{Анотація}

Статтю присвячено проблемі підвищення точності обліку впливу земної атмосфери на результати вимірювань відстаней, здійснюваних за допомогою електромагнітних хвиль. Основними впливовими факторами при таких вимірюваннях є відмінність швидкості поширення електромагнітного сигналу в атмосфері від швидкості світла у вакуумі, а також рефракційне викривлення траєкторії, по якій поширюється сигнал.

Для виключення впливу атмосфери використовуються спеціальні поправки, які вводяться в результати вимірювань із метою компенсації зазначених вище впливових факторів. Найважливішу роль серед них відіграє поправка, що враховує середньоінтегральний уздовж вимірюваної траси показник заломлення повітря.

Наразі, як правило, застосовуються модельні методи визначення поправки, яка враховує середньоінтегральний показник заломлення повітря. Ці методи використовують точкову апроксимацію неперервних функцій, які описують просторовий розподіл температури, тиску і вологості повітря на вимірюваній трасі, а також подання кінцевою сумою певного інтеграла, що задає точне співвідношення для поправки. У зв'язку із зазначеними обмеженнями в рамках зазвичай використовуваних модельних методів не завжди вдається домогтися необхідної точності результатів вимірювання відстаней. Що стосується відомих апаратурних методів, які потенційно є більш точними, то вони все ще перебувають на стадії розробки. У зв'язку з цим розглядаються нові можливості підвищення точності модельних методів, зокрема, нещодавно запропонованого градієнтного методу. 
Проведено теоретичні дослідження точності градієнтного методу визначення середньоінтегрального показника заломлення повітря при далекомірних вимірюваннях на приземних трасах. Показано, що він є більш точним, ніж відомий метод трапецій. Розглянуто отримані з використанням інтерполяційних багаточленів Ерміта рівняння вимірювань градієнтного методу, справедливі при нерівномірному розбитті вимірюваної траси точками, в яких визначаються локальні значення показника заломлення. Обгрунтовано вимоги до процедури і точності вимірювань параметрів, необхідних для визначення градієнтів показника заломлення повітря в кінцевих точках траси в рамках градієнтного методу.

Результати виконаних досліджень дають суворе обгрунтування новим методикам визначення середньоінтегрального показника заломлення повітря на навколоземних трасах із неоднорідним профілем підстильної поверхні за наявності значних перепадів висот.

Ключові слова: далекомірні вимірювання, середньоінтегральний показник заломлення повітря, інтерполяція, багаточлен Ерміта.

\title{
Анализ точности градиентного метода определения среднеинтегрального показателя преломления воздуха
}

\author{
П.И. Неежмаков, А.В. Прокопов
}

Национальный научный центр “Институт метрологии”, ул. Мироносицкая, 42, 61002, Харьков, Украина alexander.prokopov@metrology.kharkov.ua

\section{Аннотация}

Статья посвящена проблеме повышения точности учета влияния земной атмосферы на результаты измерений расстояний, осуществляемых с помощью электромагнитных волн. Основными влияющими факторами при таких измерениях являются отличие скорости распространения электромагнитного сигнала в атмосфере от скорости света в вакууме, а также рефракционное искривление траектории, по которой распространяется сигнал.

Для исключения влияния атмосферы используются специальные поправки, которые вводятся в результаты измерений с целью компенсации указанных выше влияющих факторов. Наиболее важную роль среди них играет поправка, учитывающая среднеинтегральный вдоль измеряемой трассы показатель преломления воздуха.

В настоящее время, как правило, применяются модельные методы определения поправки, учитывающей среднеинтегральный показатель преломления воздуха. Эти методы используют точечную аппроксимацию непрерывных функций, описывающих пространственное распределение температуры, давления и влажности воздуха на измеряемой трассе, а также представление конечной суммой определенного интеграла, задающего точное соотношение для поправки. В силу указанных ограничений в рамках обычно используемых модельных методов не всегда удается добиться требуемой точности результатов измерения расстояний. В связи с этим рассматриваются новые возможности повышения точности модельных методов, в частности, недавно предложенного градиентного метода.

Проведены теоретические исследования точности градиентного метода определения среднеинтегрального показателя преломления воздуха при дальномерных измерениях на приземных трассах. Показано, что он является более точным, нежели известный метод трапеций. Рассмотрены полученные с использованием интерполяционных многочленов Эрмита уравнения измерений градиентного метода, справедливые при неравномерном разбиении измеряемой трассы точками, в которых определяются локальные значения показателя преломления. Обоснованы требования к процедуре и точности измерений параметров, необходимых для определения градиентов показателя преломления воздуха в концевых точках трассы в рамках градиентного метода.

Результаты выполненных исследований дают строгое обоснование новым методикам определения среднеинтегрального показателя преломления воздуха на околоземных трассах с неоднородным профилем подстилающей поверхности при наличии значительных перепадов высот.

Ключевые слова: дальномерные измерения, среднеинтегральный показатель преломления воздуха, интерполяция, многочлен Эрмита. 


\section{References}

1. Bol'shakov V.D., Deymlikh F., Golubev A. N., Vasil'yev V.P. Radiogeodezicheskiye $i$ elektroopticheskiye izmereniya [Radio geodetic and electro-optical measurements]: textbook for higher education institutions. Moscow, Nedra, 1985. 303 p. (in Russian).

2. Andrusenko A. M., Danil'chenko V.P., Prokopov A.V., Ponomarev V. I., Lukin I. V. Metody $i$ sredstva pretsizionnoy lazernoy dal'nometrii [Methods and means of precision laser ranging]. Moscow, Standards Publishing House, 1987. 224 p. (in Russian).

3. Ostrovskiy A.L., Dzhuman B. M., Zablotskiy F. D., Kravtsov N.I. Uchet atmosfernykh vliyaniy na astronomo-geodezicheskiye izmereniya [Accounting for atmospheric influences on astronomical and geodetic measurements]. Moscow, Nedra, 1990. 235 p. (in Russian).

4. Kravtsov Yu.A., Orlov Yu.I. Geometricheskaya optika neodnorodnykh sred [Geometrical optics of inhomogeneous media]. Moscow, Nauka, 1980. 304 p. (in Russian).

5. Brazhnichenko A. V., Prokopov A. V., Remayev Ye.V. Novyye metody ucheta vliyaniya zemnoy atmosfery na tochnost' dal'nomernykh izmereniy [New methods of taking into account the influence of the earth's atmosphere on the accuracy of distance measurements]. Izmeritel'naya tekhnika - Measurement Techniques, 1990, no. 10, pp. 15-17 (in Russian).

6. Kravchenko M., Neyezhmakov P., Prokopov O. Lazerna viddalemirna systema vyshchoyi tochnosti dlya liniynykh vymiryuvan' na heodynamichnykh polihonakh Ukrayiny [Laser range-finding system of higher accuracy for linear measurements on geodynamic polygons in Ukraine]. Heodynamika Geodynamics, 1998, no. 1, pp. 37-44 (in Ukrainian).

7. Prokopov A. V., Remaev E. V. Hradyentnyy metod opredelenyya sredneyntehral'noho pokazatelya prelomlenyya vozdukha [Gradient method for determining the mean integral index of air refraction]. Tez. dop. I Ukrayins'koyi naukovoyi konferentsiyi "Kompleksni doslidzhennya suchasnoyi heodynamiky zemnoyi kory" [Proceedings of the I Ukrainian Scientific Conference "Comprehensive studies of modern geodynamics of the Earth's crust"]. Alushta, September 20-26, 1993, p. 50 (in Russian).

8. Krylov V.I., Bobkov V.V., Monastyrskiy P. I. Vychislitel'nyye metody vysshey matematiki: ucheb. posob. dlya vuzov [Computational methods of higher mathematics: study guide for higher educational institutions]. Minsk, Higher School, 1972. 584 p. (in Russian).

9. Prokopov A. V. Ob integral'nom predstavlenii luchevykh uravneniy geometricheskoy optiki [On the integral representation of the ray equations of geometric optics]. Pisma v Zhurnal tekhnicheskoi fiziki - Letters to the Journal of Technical Physics, 1985, vol. 11, no. 24, pp. 1526-1529 (in Russian).

10. Prokopov A. V. Zakon prelomleniya geometroopticheskikh luchey $\mathrm{v}$ trekhmerno-neodnorodnykh sredakh [The law of refraction of geometric optical rays in three-dimensional inhomogeneous media]. Pisma v Zhurnal tekhnicheskoi fiziki - Letters to the Journal of Technical Physics, 1988, vol. 14, no. 2, pp. 107-110 (in Russian).

11. Brazhnichenko A. V., Prokopov A. V. Imitatsionnoye modelirovaniye dal'nomernykh izmereniy i yego ispol'zovaniye dlya issledovaniya metodov opredeleniya atmosfernykh popravok [Simulation modeling of distance measurements and its use for the study of methods for determining atmospheric corrections]. Tez. dokladov III Vsesoyuznoy NTK "Metrologiya $v$ dal'nometrii" [Proceedings of the III All-Union Scientific and Technical Conference "Metrology in distance measurement"]. Kharkov, October 18-20, 1988, pp. 179-181 (in Russian).

12. Berezin I.S., Zhidkov N.P. Metody vychisleniy. T. 1 [Calculation methods. Vol. 1]. Moscow, Science, 1966. 632 p. (in Russian).

13. Bakhvalov N.S., Zhidkov N.P., Kobel'kov G. M. Chislennyye metody. [Numerical methods]. Moscow, Nauka, 1987. 600 p. (in Russian).

14. Neyezhmakov P., Prokopov A., Skliarov V. On the accounting for the influence of the Earth's atmosphere on the results of distance measurement realized by lasers. Journal of Physics: Conf. Series 1065 (2018) 142008. doi:10.1088/17426596/1065/14/142008

15. Neyezhmakov P., Prokopov A., Trevogo I. K teorii gradiyentnogo metoda opredeleniya sredneintegral'nogo pokazatelya prelomleniya vozdukha pri dal'nomernykh izmereniyakh na prizemnykh trassakh [On the theory of the gradient method for determining the mean integral refractive index of air in long-range measurements on surface traces]. Suchasni dosyagnennya geodezychnoi nauky ta vyrobnytstva - Modern achievements of geodesic science and industry, 2018, no. II (36), pp. 28-31 (in Russian). 